\title{
Improving cardiovascular disease management in Australia: NPS MedicineWise
}

\section{Svetla V Gadzhanova PhD MSC Research Fellow \\ Elizabeth E Roughead PhD, MAppSc, BPharm ARC Future Fellow \\ Mark J Bartlett BSc, MPH, GradDipAppEpi Senior Epidemiologist \\ IUniversity of South Australia, Adelaide, SA. \\ 2 Impact and Outcome Evaluation, NPS MedicineWise Sydney, NSW. \\ svetla.gadzhanova@ unisa.edu.au}

MJA 2013; 199: 192-195 doi:10.5694/mjal2.11779

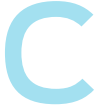
ardiovascular disease (CVD) is the largest cause of premature death in Australia; it accounted for over a third of all deaths in 2007. ${ }^{1}$ Over the past decade, NPS MedicineWise (previously known as the National Prescribing Service) implemented a number of educational programs on cardiovascular management in primary care, including two programs on the use of antithrombotics in atrial fibrillation (AF) and secondary stroke prevention, ${ }^{2,3}$ as well as programs for improving management of heart failure. ${ }^{4-6}$ NPS MedicineWise used a mix of interventions, both passive (eg, written education materials) and active (eg, one-on-one educational visits, general practitioner clinical audits, case studies), to deliver these programs, to maximise reach among GPs and to reinforce program key messages. Educational visits have been shown to be effective in changing health professional practice. ${ }^{7}$

The veteran community in Australia is further supported to achieve optimal use of medicines through the Veterans' Medicines Advice and Therapeutics Education Services (Veterans' MATES) program. $^{8}$ In addition to the NPS MedicineWise programs, one of the Veterans' MATES interventions also targeted warfarin use. ${ }^{9}$

The aim of this research was to evaluate the effect of these NPS MedicineWise interventions on the use of medicine and medical tests. The research focused on evaluating the effect of the key educational messages targeted in the interventions, which were to:

- consider warfarin in all patients with atrial fibrillation and who are at moderate-to-high risk of stroke, and aspirin in those at low risk (delivered as part of the 2003 and 2009 therapeutic programs on antithrombotic use in atrial fibrillation and secondary stroke prevention ${ }^{2,3}$ );

- consider aspirin as the drug of choice for secondary stroke prevention (delivered as part of the 2003 and 2009 therapeutic programs on antithrombotic use in atrial fibrillation and secondary stroke prevention ${ }^{2,3}$ );

\begin{abstract}
Objectives: To determine the impact of four NPS MedicineWise programs targeting quality use of medicines in cardiovascular management in primary care.

Design: Interrupted time-series analysis using the Department of Veterans' Affairs (DVA) claims dataset from 1 January 2002 to 31 August 2010. We examined the use of antithrombotics in people with atrial fibrillation and in those who had had a stroke, and the use of echocardiography and spironolactone in the population with heart failure.
\end{abstract}

Participants: All veterans and their dependants in Australia who had received cardiovascular medicines or health services related to the targeted intervention.

Intervention: NPS MedicineWise national programs to improve cardiovascular management in primary care, which included prescriber feedback, academic detailing, case studies and audits as well as printed educational materials.

Main outcome measures: Changes in medication and health service use before and after the interventions.

Results: All national programs were positively associated with significant improvements in related prescribing or test request practice. The interventions to improve the use of antithrombotics resulted in a $1.27 \%(95 \% \mathrm{Cl}, 1.26 \%-1.28 \%)$ and $0.63 \%(95 \% \mathrm{Cl}, 0.62 \%-0.64 \%)$ relative increase in the use of aspirin or warfarin in the population with atrial fibrillation 6 and 12 months after the program, respectively, and in a $1.51 \%(95 \% \mathrm{Cl}, 1.49 \%-1.53 \%)$ relative increase in the use of aspirin as monotherapy for secondary stroke prevention 12 months after the intervention. The heart failure programs resulted in a 3.69\% $(95 \% \mathrm{Cl}, 3.67 \%-$ $3.71 \%$ ) relative increase in the use of low-dose spironolactone and a $4.31 \%$ (95\% $\mathrm{Cl}, 4.27 \%-4.35 \%$ ) relative increase in the use of echocardiogram tests 12 months after the intervention.

Conclusions: NPS MedicineWise programs were effective in achieving positive changes in medicine and health service use for patients with cardiovascular diseases.

- confirm heart failure with an echocardiogram (delivered as part of the therapeutic program on heart failure management from $2008^{6}$ ); and - use low-dose spironolactone in moderate-to-severe heart failure as it confers additional mortality benefit for patients (part of the 2004 and 2008 programs on heart failure management $t^{5,6}$ ).

\section{Methods}

\section{Data source}

We conducted time-series analyses using the Department of Veterans' Affairs (DVA) health claims database. It provides details on all subsidised prescription medicines, medical and allied health services and hospitalisations for veterans. Overall, $60 \%$ of the DVA population are men and the mean age is 80 years (SD, 9.8 years).$^{10}$

\section{Study design}

Monthly time series were established between 1 January 2002 and 31
August 2010 to evaluate the effect of the key educational messages. The selection criteria for the populations of interest, contribution of persontime, and the monthly prevalence are described in Box 1.

The monthly prevalence of medicine and medical test use was calculated as the proportion of the population receiving a specific medicine or test in a given month in the population of interest. In calculating the population using a specific medicine each month, a prescription duration estimate was applied, which was calculated from the data and reflected the period within which $75 \%$ of prescriptions for that medicine were refilled, as sensitivity analysis has shown that the 75th percentile is most likely to represent the period of actual consumption of a medicine. To account for the ageing population, rates were age-standardised using the veteran population in January 2002.

\section{Statistical analyses}

Interrupted time-series modelling with change points at the time of the inter- 
1 Study design: key messages of four NPS MedicineWise programs, selection criteria and key definitions

\begin{tabular}{|c|c|c|c|}
\hline Key message & Selection criteria for the population of interest & Person-time & Monthly prevalence \\
\hline $\begin{array}{l}\text { Consider aspirin } \\
\text { or warfarin in AF }\end{array}$ & $\begin{array}{l}\text { At least one hospital admission between } 2002 \text { and } \\
2010 \text { with primary diagnosis for AF (ICD codes I48.0 } \\
\text { to 148.9) }\end{array}$ & $\begin{array}{l}\text { All months from the first } \\
\text { hospitalisation to death } \\
\text { or end of study }\end{array}$ & $\begin{array}{l}\text { Proportion of patients } \\
\text { given aspirin or warfarin }\end{array}$ \\
\hline $\begin{array}{l}\text { Consider aspirin as } \\
\text { a monotherapy in } \\
\text { secondary stroke } \\
\text { prevention }\end{array}$ & $\begin{array}{l}\text { At least one hospitalisation between } 2002 \text { and } 2010 \\
\text { with primary diagnosis for transient ischaemic attack } \\
\text { (ICD code G45.0 to G45.9) or ischaemic stroke (ICD } \\
\text { code I63.0 to I63.9) }\end{array}$ & $\begin{array}{l}\text { All months from the first } \\
\text { hospitalisation to death } \\
\text { or end of study }\end{array}$ & $\begin{array}{l}\text { Proportion of patients given } \\
\text { aspirin as a monotherapy }\end{array}$ \\
\hline $\begin{array}{l}\text { Confirm an incident } \\
\text { HF event with an } \\
\text { echocardiogram }\end{array}$ & $\begin{array}{l}\text { First ever hospitalisation for HF (ICD codes } 150.0 \\
\text { to I50.9, } 111.0,113.0,113.2 \text { ) or first ever dispensing } \\
\text { of medications indicative of HF* between } 2002 \\
\text { and } 2010\end{array}$ & $\begin{array}{l}\text { Just for the month of } \\
\text { the incident HF event }\end{array}$ & $\begin{array}{l}\text { Proportion of patients who had } \\
\text { an echocardiogram (MBS item } \\
\text { numbers } 55113,55118 \text { ) in the } \\
3 \text { months before the incident } \\
\text { HF event }\end{array}$ \\
\hline $\begin{array}{l}\text { Use low-dose } \\
\text { spironolactone } \\
\text { ( } 25 \mathrm{mg} \text { ) in patients } \\
\text { with HF }\end{array}$ & $\begin{array}{l}\text { Hospitalisation for HF or dispensing of medications } \\
\text { indicative of HF* }\end{array}$ & $\begin{array}{l}\text { All months with a } \\
\text { hospitalisation for } \mathrm{HF} \text { or } \\
\text { dispensing of medications } \\
\text { indicative of } \mathrm{HF}^{*}\end{array}$ & $\begin{array}{l}\text { Proportion of patients given } \\
\text { low-dose spironolactone } \\
(25 \mathrm{mg})\end{array}$ \\
\hline
\end{tabular}

$\mathrm{AF}=$ atrial fibrillation. $\mathrm{HF}=$ heart failure. $\mathrm{ICD}=$ International Classification of Diseases (10th revision). MBS = Medicare Benefits Schedule. $*$ Medications indicative of HF included rennin-angiotensin system medications concurrent with loop diuretics or the heart failure-specific beta-blockers bisoprolol, metoprolol succinate or carvedilol.

ventions was used to determine the impact of the NPS MedicineWise interventions. Analyses controlled for the baseline trend, seasonality and any autocorrelation evident in the time series. Change-in-trend and changein-level terms were included to determine the impact of interventions. Additional terms were modelled to account for other events that could have influenced the time series, including changes in copayments in January 2005, and the impact of the Veterans' MATES program aiming to improve medication use for Australian war veterans. ${ }^{8}$ Stepwise backward elimination was used to select the most parsimonious model, the one that included only statistically significant predictors. The intervention effect from the most recent NPS MedicineWise intervention was reported as: ${ }^{11}$

- absolute effect, expressed as the absolute difference between the model-estimated values of the outcome after the intervention and values estimated as if the intervention had not occurred (ie, without any postintervention effects in the model); - relative change in the outcome associated with the intervention, expressed as a percentage increase or decrease; and

- average month-to-month change (\%) for the period since the most recent intervention calculated as ratio of the model-estimated values in each month to the values from the previous month, for the trend line with and without the intervention.
Data extraction and analysis were performed using SAS version 9.3 (SAS Institute Inc).

\section{Ethics approval}

An ethics protocol for the study was approved by the University of South Australia Human Research Ethics Committee (ethics protocol P218/09) and the Department of Veterans' Affairs Human Research Ethics Committee (E009/0190).

\section{Results}

Of the four areas evaluated, all were associated with improvement in practice at 6 to 12 months after the most recent intervention, with relative

\section{Results: summary of impact of programs targeting quality use of medicines in cardiovascular management in primary care}

\begin{tabular}{|c|c|c|c|c|c|}
\hline \multirow[b]{2}{*}{$\begin{array}{l}\text { Key message (population of } \\
\text { interest in January 2002) }\end{array}$} & \multirow[b]{2}{*}{$\begin{array}{l}\text { Monthly prevalence } \\
\text { in January } 2002\end{array}$} & \multicolumn{2}{|c|}{$\begin{array}{l}\text { Month-to-month change (\%) in the } \\
\text { trends after most recent intervention }\end{array}$} & \multicolumn{2}{|c|}{$\begin{array}{l}\text { Absolute and relative effect }(95 \% \mathrm{Cl}) \text { after } \\
\text { most recent intervention }\end{array}$} \\
\hline & & $\begin{array}{l}\text { Trend with } \\
\text { intervention }\end{array}$ & $\begin{array}{l}\text { Trend without } \\
\text { intervention }\end{array}$ & Absolute increase & Relative increase \\
\hline $\begin{array}{l}\text { Consider aspirin or warfarin } \\
\text { in AF ( } 2863 \text { patients } \\
\text { with AF) }\end{array}$ & $\begin{array}{l}1642 / 2863 \text { patients } \\
(57.35 \%) \text { were given } \\
\text { warfarin or aspirin }\end{array}$ & $\begin{array}{l}\text { Initial increase of } \\
1.32 \%(P=0.03) \text {, } \\
\text { then monthly } \\
\text { change of } \\
(-0.06 \%)\end{array}$ & $0.04 \%$ & $\begin{array}{l}0.80 \% \\
(0.19 \%-1.41 \%) \text { at } 6 \\
\text { months and } 0.39 \% \\
(0.13 \%-1.00 \%) \\
\text { at } 12 \text { months }\end{array}$ & $\begin{array}{l}1.27 \%(1.26 \%-1.28 \%) \\
\text { at } 6 \text { months and } 0.63 \% \\
(0.62 \%-0.64 \%) \\
\text { at } 12 \text { months }\end{array}$ \\
\hline $\begin{array}{l}\text { Consider aspirin as a } \\
\text { monotherapy in secondary } \\
\text { stroke prevention ( } 2015 \\
\text { patients with TIA or } \\
\text { ischaemic stroke) }\end{array}$ & $\begin{array}{l}333 / 2015 \text { patients } \\
\text { (16.53\%) were } \\
\text { given aspirin as a } \\
\text { monotherapy }\end{array}$ & $0.29 \%$ & $0.03 \%$ & $\begin{array}{l}0.36 \% \\
(0.04 \%-0.68 \%) \\
\text { at } 12 \text { months }\end{array}$ & $\begin{array}{l}1.51 \% \\
(1.49 \%-1.53 \%) \\
\text { at } 12 \text { months }\end{array}$ \\
\hline $\begin{array}{l}\text { Confirm an incident HF event } \\
\text { with an echocardiogram } \\
\text { ( } 959 \text { patients with } \\
\text { incident HF) }\end{array}$ & $\begin{array}{l}139 / 959 \text { patients } \\
(14.49 \%) \text { had an } \\
\text { echocardiogram in } \\
\text { the past } 3 \text { months }\end{array}$ & $0.45 \%$ & $0.15 \%$ & $\begin{array}{l}0.77 \% \\
(0.07 \%-1.47 \%) \\
\text { at } 12 \text { months }\end{array}$ & $\begin{array}{l}4.31 \% \\
(4.27 \%-4.35 \%) \\
\text { at } 12 \text { months }\end{array}$ \\
\hline $\begin{array}{l}\text { Use low-dose spironolactone } \\
\text { ( } 25 \mathrm{mg}) \text { in patients with } \\
\text { HF ( } 22176 \text { patients } \\
\text { with HF) }\end{array}$ & $\begin{array}{l}2362 / 22176 \text { patients } \\
(10.65 \%) \text { were } \\
\text { given low-dose } \\
\text { spironolactone }\end{array}$ & $0.18 \%$ & $0.05 \%$ & $\begin{array}{l}0.41 \% \\
(0.14 \%-0.69 \%) \\
\text { at } 12 \text { months }\end{array}$ & $\begin{array}{l}3.69 \% \\
(3.67 \%-3.71 \%) \\
\text { at } 12 \text { months }\end{array}$ \\
\hline
\end{tabular}

$\mathrm{AF}=$ atrial fibrillation. $\mathrm{HF}=$ heart failure $\mathrm{TIA}=$ transient ischaemic attack 
3 Monthly time series showing effects of NPS MedicineWise educational programs targeting quality use of medicines in cardiovascular management

A) Estimated impact of NPS MedicineWise programs on the use of warfarin and aspirin in patients with atrial fibrillation

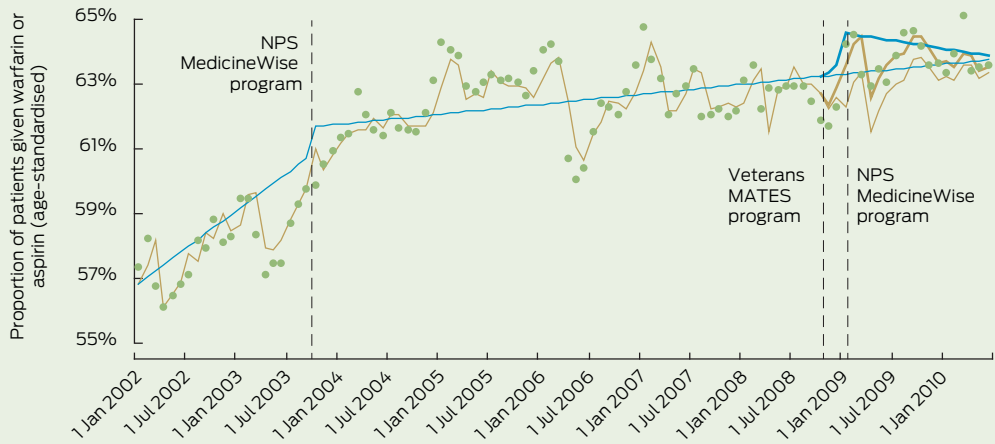

B) Estimated impact of NPS MedicineWise programs on the use of aspirin as a monotherapy in secondary stroke prevention

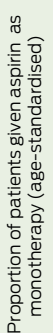

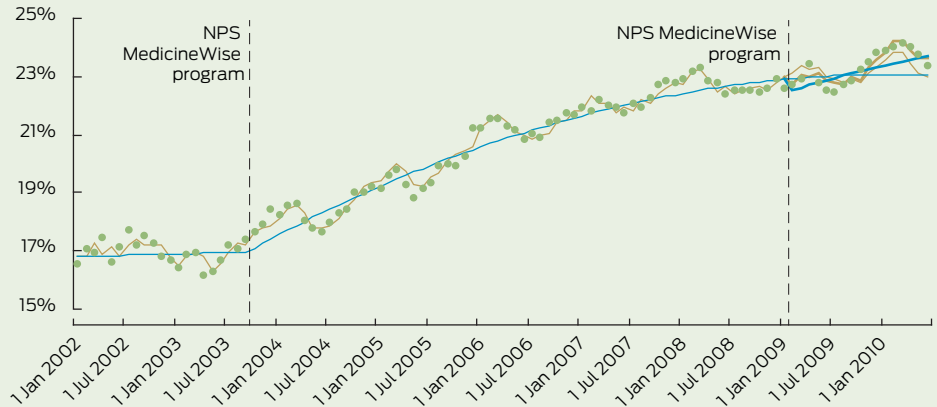

C) Estimated impact of the MedicineWise program on the rate of echocardiogram tests requested in the 3

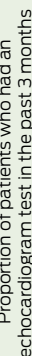

2

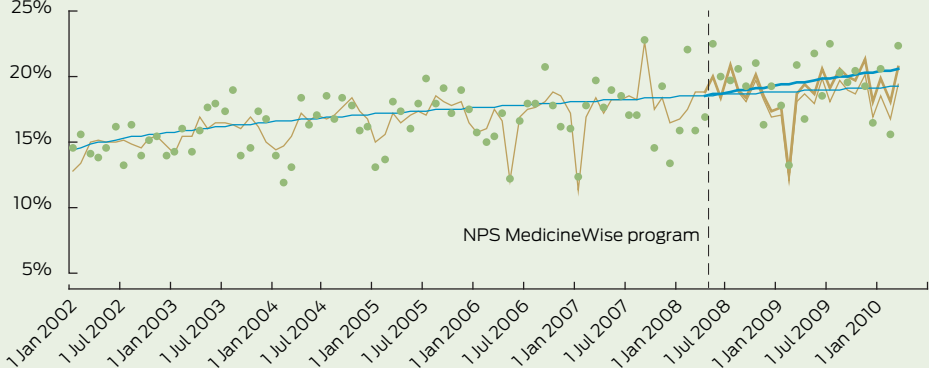

D) Estimated impact of NPS MedicineWise programs on the use of low-dose spironolactone in patients

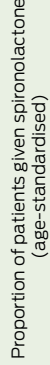

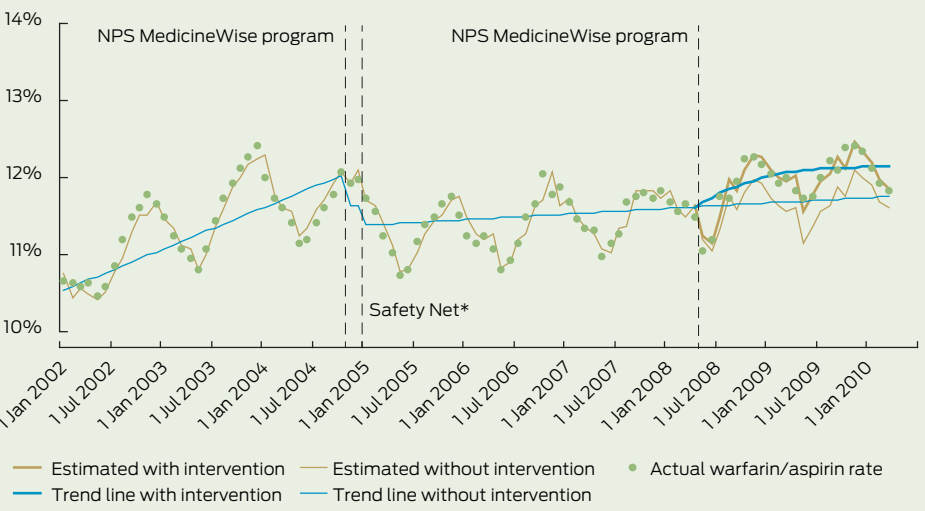

* The changes in Safety Net copayments in January 2005 contributed to the decrease in the rate around that time. effect sizes ranging from $1.27 \%$ to $4.31 \%$ (Box 2 and Box 3 ). Three of the trend lines showed a sustained constant month-to-month increase (Box 2 and Box 3). Further, the monthly increase in the rate with the intervention effects was 3-10 times higher than the increase shown by the trend line without the intervention. For example, the rate of aspirin use in secondary stroke prevention, when accounting for the effect of the February 2009 program, increased by $0.29 \%$ each month (compared with the previous month), compared with $0.03 \%$ monthly increase in the rate without the intervention.

There was an abrupt increase in the use of aspirin and warfarin in $\mathrm{AF}$ around the time of the interventions, followed by a slow decrease in the trend over time towards the estimated rate without intervention (Box 3 ).

\section{Discussion}

Our results showed that over half of the population with a prior hospitalisation for $\mathrm{AF}$ received warfarin or aspirin treatment. The results are comparable with an American study that reported use of warfarin by $42 \%$ of patients with $\mathrm{AF}$ at high risk of stroke, and by $44 \%$ of patients with moderate stroke risk. ${ }^{12}$

Aspirin significantly reduces the risk of stroke in patients who experienced a transient ischaemic attack (TIA) or stroke, ${ }^{13}$ and should be given as soon as possible after onset and continued as long-term antiplatelet therapy. ${ }^{14}$ Our analysis showed that an increasing number of patients were receiving aspirin as a monotherapy after a TIA or ischaemic stroke event, reaching around one-quarter of the at-risk group in March 2010.

Symptoms of heart failure can be non-specific, and many at-risk patients remain undiagnosed in the early stages. ${ }^{15}$ If heart failure is suspected, further investigations are required, including an echocardiogram, as it provides information about the type of heart failure and thus treatment implications. ${ }^{16,17}$ We found that echocardiography was requested before diagnosis of incident heart failure for one in five at-risk people.

Low-dose spironolactone $(25 \mathrm{mg})$, when added to loop diuretic and 
angiotensin-converting enzyme inhibitor therapy, can improve prognosis in patients with moderate-tosevere heart failure. ${ }^{18}$ Around $11 \%$ of our patients with heart failure were given low-dose spironolactone. This rate is similar to the $11 \%$ rate of spironolactone use in patients with chronic heart failure reported by a Dutch study in $2000 .^{19}$

This evaluation has shown that the NPS MedicineWise programs delivered in primary care were effective in improving prescribing and service use in cardiovascular management, with relative effects ranging from $0.63 \%$ to $4.31 \% 12$ months after the intervention. The NPS MedicineWise used a combination of passive and active interventions to reinforce their key messages. Active components such as one-to-one educational visits have been shown to be effective in improving health professional practice, providing small but consistent changes in prescribing (median, $4.8 \%$ ), and small-to-moderate effects on other professional performance (eg, screening tests). ${ }^{7,20}$ Although small to moderate, such changes might be potentially important when hundreds of patients are affected. ${ }^{7}$

There are several limitations to our study. There is no way to ascertain whether the GPs who are responsible for changes in prescribing and medical test requests are also the ones who received the information through the NPS MedicineWise program or other sources. The data does not provide direct diagnostic information; thus our analyses rely on previous hospitalisation records, including documentation of a medication regimen to define the presence of a condition, and therefore there are likely to be a number of people with the conditions of interest who are omitted from the study population.

Nevertheless, the results of this study are likely to be generalisable to the overall Australian population, as there are only slightly more general practice visits (rate ratio, 1.17; $P<0.05$ ) and hospitalisations (rate ratio, $1.21 ; P<0.05)$ in the veteran population per year than in other Australians aged 40 years and over. ${ }^{21}$ Veterans receive slightly more prescriptions annually than other Australians aged 40 years and over (rate ratio, $1.13 ; P<0.05) .^{21}$ This suggests that our study results are likely to reflect the general Australian population, but may slightly overestimate the utilisation rates.

In conclusion, NPS MedicineWise programs delivered in primary care are associated with significant changes in drug use patterns and service use in cardiovascular management. The quality use of medicines programs implemented as an initiative of the National Medicines Policy have the potential to improve Australia's medicines and health environment.

Acknowledgements: This study was funded by NPS MedicineWise, Australia. We acknowledge the support of the Department of Veterans' Affairs, which provided data for the conduct of these analyses.

Competing interests: NPS MedicineWise approved this manuscript before submission.

Received 6 Dec 2012, accepted 25 Jun 2013.

1 Australian Institute of Health and Welfare. Australia's health 2010. Canberra: AlHW, 2010. (AlHW Cat. No. AUS 122; Australia's Health No. 12.) http://www.aihw.gov.au/publication-detail/?id= 6442468376 (accessed Jun 2013).

2 National Prescribing Service Limited. Using antithrombotics: maximising benefits; minimising risks. Prescribing Practice Review 24; Dec 2003. http://www.nps.org.au/_data/assets/pdf_file/ 0008/16955/ppr24.pdf (accessed Jun 2013).

3 National Prescribing Service Limited. Antiplatelet and anticoagulant therapy in stroke prevention. Prescribing Practice Review 44; Mar 2009. http:// www.nps.org.au/_data/assets/pdf_file/0008/ 68813/PPR 44_Anticoagulants_0309.pdf(accessed Jun 2013).

4 National Prescribing Service Limited. Medication review for your patients with heart failure. Prescribing Practice Review 8; May 2000. http:// www.nps.org.au/_data/assets/pdf_file/0003/ 16923/ppr08.pdf (accessed Jun 2013).

5 National Prescribing Service Limited. Improving outcomes for heart failure patients. Prescribing Practice Review 28; Nov 2004. http://www.nps. org.au/ data/assets/pdf file/0007/16963/ ppr28.pdf (accessed Jun 2013).

6 National Prescribing Service Limited. Improving outcomes in chronic heart failure. Prescribing Practice Review 41; May 2008. http://www.nps. org.au/_data/assets/pdf_file/0008/35495/ PPR41 Improving outcomes chronic heart failure 0508.pdf (accessed Jun 2013).

7 O'Brien MA, Rogers S, Jamtvedt G, et al. Educational outreach visits: effects on professional practice and health care outcomes. Cochrane Database Syst Rev 2007; (4): CD000409.

8 Australian Government Department of Veterans' Affairs. Veterans' Medicines Advice and Therapeutics Education Services (Veterans' MATES). http://www.veteransmates.net.au (accessed Nov 2012).

9 Australian Government Department of Veterans' Affairs. The SAFE approach to warfarin therapy. Veterans' MATES Therapeutic brief 17; Nov 2008. https://www.veteransmates.net.au/ VeteransMATES/documents/module_materials/ M17_TherBrief.pdf (accessed Jun 2013).

10 Australian Government Department of Veterans' Affairs. Treatment population statistics December 2011. Canberra: DVA, 2011. http://www.dva.gov.au/ aboutDVA/Statistics/Documents/TpopDec2011 .pdf (accessed Jun 2013).

11 Wagner AK, Soumerai SB, Zhang F, Ross-Degnan D. Segmented regressing analysis of interrupted time series studies in medication use research. J Clin Pharm Ther 2002; 27: 299-309.

12 Zimetbaum PJ, Thosani A, Yu HT, et al. Are atrial fibrillation patients receiving warfarin in accordance with stroke risk? Am J Med 2010; 123: 446-453.

13 Acelajado MC, Oparil S. Antiplatelet therapy for transient ischemic attack.J Clin Hypertens (Greenwich) 2012; 14:103-111.

14 Neurology Expert Group. Therapeutic guidelines: neurology. Version 3. Melbourne: Therapeutic Guidelines Limited, 2008.

15 Abhayaratna WP, Smith WT, Becker NG, et al. Prevalence of heart failure and systolic venticula dysfunction in older Australians: the Canberra Heart Study. Med J Aust 2006; 184: 151-154.

16 National Heart Foundation of Australia and the Cardiac Society of Australia and New Zealand. Guidelines for the prevention, detection and management of chronic heart failure in Australia. Updated October 2011. http://www.

heartfoundation.org.au/information-forprofessionals/Clinical-Information/Pages/heartfailure.aspx (accessed Jun 2013).

17 Scottish Intercollegiate Guidelines Network. Management of chronic heart failure: a national clinical guideline. SIGN Guideline No. 95, 2007. www.sign.ac.uk/pdf/sign95.pdf (accessed Jun 2013).

18 Pitt B, Zannad F, Remme WJ, et al. The effect of spironolactone on morbidity and mortality in patients with severe heart failure. N Engl J Med 1999; 341: 709-717.

19 Pont LG, Sturkenboom MC, van Gilst WH, et al Trends in prescribing for heart failure in Dutch primary care from 1996 to 2000. Pharmacoepidemiol Drug Saf 2003; 12: 327-334.

20 Oxman DA, Thomson MA, Davis DA, Haynes RB. No magic bullets: a systematic review of 102 trials of interventions to improve professional practice. CMAJ 1995; 153: 1423-1431.

21 Lloyd J, Anderson P. Veterans's use of health services. Canberra: Australian Institute of Health and Welfare, 2008. (AlHW Cat. No. AGE 51.) http:// www.aihw.gov.au/publication-detail/?id= 6442468071 (accessed Jun 2013).

\section{When too much MJA and MJA InSight is never enough.}

Follow us on Twitter (@theMJA) and like us on Facebook (https://www.facebook.com/theMJA)

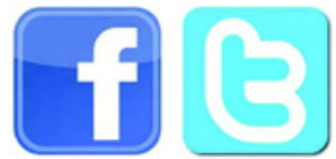

